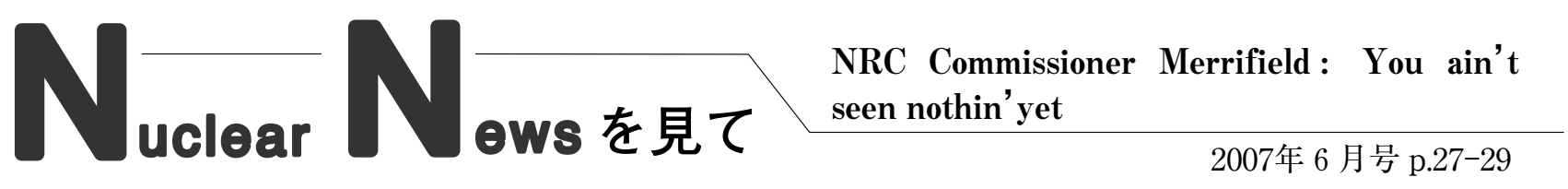

\title{
まだ何も見えてはいないのだ！
}

9 年間の NRC 委員職離任を前に, J. S. Merrifield 氏 が RIC (2007 Regulatory Information Conference， 3 月) で講演した内容から，「今後の原子力安全規制上の課題」 としている部分を取り上げる。わが国の規制のみなら ず，産業界にも示唆に富んでいると思えるからである。

氏は， 9 年間を短く振り返った後，大きく 4 つの分野 で今後を展望している。(1)新規プラント対応，(2)寿命延 伸対応，(3)高レベル廃棄物問題，(4)国際協力である。

\section{(1) 新規プラント対応}

氏は，この 20 年で米国の原子力発電所が倍増すること を現実として受け止め, 今後の一括認可 $(\mathrm{COL})$ を効率 的に進めるために, 以下の 3 点を特に強調している。

環境法 (NEPA)の要求を満たすためのレビュープロセ スが肥大化している。それはNEPA(あるいは議会)が 求めた要求を超えているかもしれない。NRCとして, その合理化を考えなければならない。

法定の公聴会で取り上げる範囲と深さが行き過ぎてい ないか。1954年に議会がこれを定めた当時の要求を遥か に越えてしまっているのではないか。3〜4時間の一度 の NRC ヒアリングで十分ではないのか。

氏はまた，一括認可プロセスも短縮すべきとしてい る。公聴会を含めて目標を $24 \sim 26$ ケに設定すべく, 効 率的な環境および安全レビュープロセス，タイムリーな ASLB 公聴会, NRC のリーダシップが必要と指摘して いる。

\section{(2) 寿命延伸対応}

既存プラントの約半数は 20 年の延伸認可が出た。更な る20年延伸に何が必要かを考えておく必要があるとして いる。氏によれば，炉容器自体は80年使用に耐えるだろ うが, 埋め込み配管やケーブル, 計装制御機器はどうか, 蒸気発生器や非常用ディーゼル発電機はどうか，などを 早期に見極めておきたいとしている。多くの既存プラン トは経済面から80年への延伸申請をするだろうことに NRC も備える必要があるとしている。

\section{(3) 高レベル廃棄物問題}

Yucca Mountain 計画の遅れは,「DOE の管理面の不 備」と見なし，スウェーデン，フィンランドの先例に習 えば，解決は時間の問題としている。

\section{（4） 国際協力}

原子力パートナー国とは相互に学ぶことがますます大 事になり，原子力の新導入国には世界的な規制を進める 上で米国の果たすべき役割は増している。NRCが，そ の国際的役割をより強めるために議会も資金を与えてく れるよう訴えている。

(文責 日本原子力産業協会・小西俊雄) 